\title{
Phenotype of Patients With Charcot-Marie- Tooth With the p.His123Arg Mutation in GDAP1 in Northern Finland
}

Maria Lehtilahti, MD, Mika Kallio, MD, PhD, Kari Majamaa, MD, PhD, and Mikko Kärppä, MD, PhD

Neurol Genet 2021;7:e629. doi:10.1212/NXG.0000000000000629
Correspondence

Dr. Kärppä

mikko.karppa@oulu.fi

\section{Abstract}

\section{Background and Objectives}

Mutations in the ganglioside-induced differentiation-associated protein 1 (GDAP1) gene cause autosomal dominant or autosomal recessive forms of Charcot-Marie-Tooth disease (CMT). Our aim was to study the clinical phenotype of patients with CMT caused by heterozygous p.His123Arg in GDAP1.

\section{Methods}

Twenty-three Finnish patients were recruited from a population-based cohort and through family investigation. Each patient was examined clinically and electrophysiologically. The Neuropathy Symptom Score and the Neuropathy Disability Score (NDS) were used in clinical evaluation.

\section{Results}

The median age at onset of symptoms was 17 years among patients with p.His123Arg in GDAP1. Motor symptoms were markedly more common than sensory symptoms at onset. All patients had distal weakness in lower extremities, and 17 (74\%) patients had proximal weakness. Muscle atrophy and pes cavus were also common. Nineteen (82\%) patients had sensory symptoms such as numbness or pain. The disease progressed with age, and the NDS increased 8.5 points per decade. Electrodiagnostic testing revealed length-dependent, sensory and motor axonal polyneuropathy. EDx findings were asymmetrical in 14 patients. Genealogic study of the families suggested a founder effect.

\section{Discussion}

We found that CMT in patients with p.His123Arg in GDAP1 is relatively mild and slow in progression.

\footnotetext{
From the Medical Research Center Oulu, University of Oulu and Oulu University Hospital (M.L., K.M., M.Kärppä); Research Unit of Clinical Neuroscience, University of Oulu (M.L., K.M., M.Kärppä); Department of Neurology, Oulu University Hospital (M.L., K.M., M.Kärppä); Department of Clinical Neurophysiology, Medical Research Center Oulu, Oulu University Hospital (M.Kallio); Research Unit of Medical Imaging, Physics and Technology, Faculty of Medicine, University of Oulu (M.Kallio), Oulu, Finland.

Go to Neurology.org/NG for full disclosures. Funding information is provided at the end of the article. 


\section{Glossary}

$\mathbf{C C V}=$ compound conduction velocity; $\mathbf{C M T}=$ Charcot-Marie-Tooth; $\mathbf{C T S}=$ carpal tunnel syndrome; GDAP1 = gangliosideinduced differentiation-associated protein 1; $\mathbf{m R S}=$ modified Rankin Scale; NCS = nerve conduction study; NDS = Neuropathy Disability Score; SCV = sensory conduction velocity.

More than 100 genes have been reported to harbor mutations that cause Charcot-Marie-Tooth (CMT) disease. ${ }^{1}$ Mutations in the gene encoding ganglioside-induced differentiation-associated protein 1 (GDAP1) are associated with autosomal recessive or autosomal dominant CMT. ${ }^{2,3}$ Recessive mutations in GDAP1 cause a severe early-onset phenotype, and many patients become nonambulatory before age 20 years. ${ }^{4,5}$ Dominant mutations cause a mild late-onset phenotype with slow progression and wide heterogeneity. ${ }^{3,6}$ Muscle weakness is the main symptom regardless whether the disease is mild late onset or severe early onset. ${ }^{5}$

GDAP1 is an integral membrane protein of the outer mitochondrial membrane, ${ }^{2}$ and it is expressed mainly in axons but also in Schwann cells. ${ }^{7}$ Mutations in the GDAP1 gene affect mitochondrial dynamics and distribution within the axon and lead to a general disruption of the mitochondrial network. ${ }^{8,9}$ Failure in calcium homeostasis, reduced production of ATP, and increased oxidative stress have been suggested to be the pathologic mechanisms in GDAP1-associated CMT. ${ }^{10}$

Our previous epidemiologic survey has enabled the identification of 31 patients with the p.His123Arg mutation in GDAP1, suggesting that this mutation in GDAP1 is a common cause of CMT in Finland. ${ }^{11}$ Here, we have examined 23 patients with p. His123Arg in GDAP1 to analyze the clinical phenotype and detailed electrophysiologic findings.

\section{Methods}

\section{Patients}

Subjects with heterozygous p.His123Arg in GDAP1 $(\mathrm{N}=28)$ were identified in a population-based survey of patients with undefined polyneuropathy in the population of Northern Ostrobothnia, Finland. ${ }^{11}$ Twenty patients consented, and 3 relatives were included.

\section{Clinical Evaluation}

Each patient was examined clinically, and all of them participated in electrodiagnostic (EDx) testing. The Neuropathy Symptom Score (NSS) and the Neuropathy Disability Score (NDS) ${ }^{12,13}$ were estimated as a part of the clinical evaluation. The NSS is abstracted from neurologic history, as the symptoms of neuropathy are scored present or absent. The scale is $0-17$, and scores $\geq 1$ were considered abnormal. The NDS is a detailed neurologic examination of deficits (scale $0-280$, scores $\geq 6$ are considered abnormal). Family history study covering first-degree relatives was conducted. The clinical severity was staged by using the modified Rankin Scale (mRS) ${ }^{14,15}$ and Staging Severity of Neuropathy, ${ }^{14}$ but quantitative sensory and autonomic examinations were not used. ${ }^{16}$ For a diagnosis of polyneuropathy, it was required that 2 or more abnormalities should be found in EDx examination, NDS, or NSS. The patient was classified as having no neuropathy, when the minimal criteria for neuropathy were not fulfilled, asymptomatic neuropathy when there were at least 2 abnormalities in EDx testing or NDS, but the NSS was 0 , symptomatic neuropathy if symptoms were also present (NSS $\geq 1$ ), and disabling neuropathy when the patient was unable to walk without assistance. ${ }^{13}$ The pedigrees of the patients with the p.His123Arg mutation in GDAP1 were constructed including 17 complete sibships and ancestors born in the 19th century. Data from population registry were used to compile the pedigrees.

\section{Electrodiagnostic Testing}

Standardized sensory, motor, and compound nerve conduction studies (NCSs) with fixed electrode distances were performed on 23 patients using a Dantec Keypoint Focus workstation (Alpine Biomed Aps, Skovlunde, Denmark). Skin temperature was kept above $30^{\circ} \mathrm{C}$ for upper and $28^{\circ} \mathrm{C}$ for lower extremities. Settings for measurements and placements of cursors for the parameters were checked manually. ${ }^{17}$ Bilateral sural and medial plantar sensory NCSs were performed with $10 \mathrm{~cm}$ fixed distance for sural and $14 \mathrm{~cm}$ for medial plantar sensory conduction velocity $(\mathrm{SCV})$. Right median and ulnar nerve antidromic SCV was measured from the index and little fingers, and compound NCSs were measured by palmar stimulation with $8 \mathrm{~cm}$ fixed distances for compound conduction velocities (CCVs) in both nerves. Antebrachial median nerve $\mathrm{CCV}$ was also measured by stimulating the nerve at the wrist and recording at the antecubital fossa. Bilateral peroneal and tibial motor NCSs were performed including measurements of $\mathrm{F}$ waves and $\mathrm{H}$ reflexes for the tibial nerve. Values were adjusted for age, height, and temperature with multiple regression, and compared with our reference material, parameters exceeding $2.5 \mathrm{SD}$ of the mean were considered abnormal. Compound muscle action potential of peroneal and tibial nerves and sensory nerve action potential of sural nerves were used to estimate asymmetry. The ratio of the lower amplitude to the higher amplitude was calculated, and the reported cutoff values based on 95th percentiles were used to define asymmetry. ${ }^{18}$ The cutoff was 0.16 for peroneal nerve, 0.37 for tibial nerve, and 0.39 for sural nerve. Asymmetry was diagnosed also, if action potentials were found on one side but not on the other side. Clinical asymmetry was defined on the basis of difference in muscle strength at the discretion of an experienced neurologist.

\section{Standard Protocol Approvals, Registrations, and Patient Consents}

The study protocol has been approved by the ethics committee of the Oulu University Hospital. All participants gave written informed consent. 
Table 1 Demography of Patients With p.His123Arg in GDAP1 According to the Severity of the Disease

\begin{tabular}{lll}
\hline & \multicolumn{2}{l}{ Severity of polyneuropathy } \\
\cline { 2 - 3 } & Symptomatic & Disabling \\
\hline Patients (men/women) & $6 / 10$ & $1 / 5$ \\
\hline Duration of the disease $(y)$ & $17(7-39)$ & $42(23-64)$ \\
\hline Age $(\mathbf{y})$ & $49(22-61)$ & $66(58-79)$ \\
\hline mRS score & $1.0(1.0-2.0)$ & $4.0(4.0)$ \\
\hline NDS & $62(33-85)$ & $103(99-118)$ \\
\hline NSS & $4.5(1.3-6.8)$ & $5.0(5.0-8.5)$ \\
\hline
\end{tabular}

Abbreviations: $\mathrm{mRS}$ = modified Rankin Scale; NDS = Neuropathy Disability Score; NSS = Neuropathy Symptom Score.

The severity of the disease was defined according to the Staging Severity of Neuropathy classification. Values are medians (interquartile ranges).

\section{Data Availability}

The data that support the findings of this study are available on reasonable request.

\section{Results}

\section{Patient Demography}

We identified 31 patients with the p.His123Arg mutation in GDAP1 giving a frequency of 10/100,000 in the adult population of the province of Northern Ostrobothnia. Twenty-three patients from 8 families (1-7 patients per family) participated in clinical neurologic evaluation and EDx examination of peripheral nerves (Table 1 and eTable 1, links.lww.com/NXG/A476). All the patients fulfilled the EDx criteria of polyneuropathy, and each family complied with autosomal dominant mode of inheritance. Factors contributing to polyneuropathy were reviewed, and 1 patient was found with a previous diagnosis of diabetes mellitus. The median age at the onset of symptoms was 17 years (range, 5-73 years), and the median age at diagnosis was 40 years (range, 6-79 years). The median duration of polyneuropathy was 24 years (range, $1-75$ years).

\section{Clinical Features}

One patient had asymptomatic neuropathy according to the Staging Severity of Neuropathy classification, whereas neuropathy was symptomatic in 16 patients and disabling in 6 patients (Table 1). The first symptoms had been motor weakness in the lower limbs of 18 patients, whereas 5 patients had had sensory symptoms at the onset. Muscle atrophy in the lower legs and pes cavus were frequent signs, as 3 patients had pes cavus, 3 had muscle atrophy, and 15 patients had both. Fourteen patients had abnormal gait that was most commonly caused by foot drop (9 patients, 39\%) or extensive muscle weakness in the legs. The 6 patients with disabling neuropathy used a walking aid. Fourteen patients reported muscle cramps. None of the patients had vocal cord palsy. Muscle weakness and decreased ankle tendon reflexes were found in all the
23 patients (Table 2). The mean NSS was 4.8 (range, $0-10$ ). Sensory symptoms, such as prickling or sensory loss, were present in 19 patients. The mean NDS was 73.3 (range, 10-135), and the mean mRS score was 2.1 (range, 0-4). Multiple regression analysis with NDS as the dependent variable revealed that age at onset and current age, but not sex, were predictors. The correlation between the age at examination and NDS was weak $\left(\mathrm{R}^{2}=0.268\right)$, but suggested an increase of 8.5 points per decade. The mean $\mathrm{mRS}$ score was 1.5 among the 12 patients younger than 54 (median) years, whereas it was 2.8 among those older than 54 years.

\section{Electrodiagnostic Testing}

EDx testing revealed sensory and motor axonal polyneuropathy in all patients (eTable 1, links.lww.com/NXG/A476). The EDx findings were asymmetrical in 14 patients including asymmetrical tibial motor response or asymmetrical peroneal motor response in 13 patients and asymmetrical sural sensory response in 1 patient. At clinical examination, the weakness of the lower extremities was asymmetrical in 11 patients (48\%). Clinical asymmetry or EDx asymmetry was found in 17 patients giving a concordance rate of $61 \%$. H reflex was absent in the lower extremities of 21 patients (93\%). There was no electrophysiologic evidence supporting segmental demyelination in the motor responses. EDx testing revealed median nerve peripheral neuropathy suggesting subclinical carpal tunnel syndrome (CTS) in 4 patients (17\%). Common causes of CTS were ruled out by laboratory tests.

\section{Pedigrees}

The 23 patients were from 8 pedigrees. The patients reported family history so that 17 complete sibships in $1-4$ generations could be identified including 87 members, 27 of whom were with polyneuropathy, and 22 participated in our clinical study. Cumulative incidence of polyneuropathy in the sibships was $48.4 \%$ at age 75 years. The percentage is compatible with autosomal dominant inheritance and suggests full penetrance (Figure 1). In the 8 pedigrees, we were able to identify 35 ancestors who preceded the patient by 2 to 4 generations,

Table 2 Clinical Characteristics of the Patients With p. His123Arg in GDAP1

\begin{tabular}{lc}
\hline Symptoms and signs & $\%$ \\
\hline Proximal weakness, upper & 22 \\
\hline Distal weakness, upper & 78 \\
\hline Proximal weakness, lower & 74 \\
\hline Distal weakness, lower & 100 \\
\hline Areflexia & 22 \\
\hline Pes cavus & 78 \\
\hline Abnormal gait & 61 \\
\hline Decreased vibration & 74 \\
\hline Sensory symptoms & 83 \\
\hline Sensory loss, pinprick or touch & 65 \\
\hline
\end{tabular}


Figure 1 Cumulative Incidence of Polyneuropathy in the Pedigrees of 23 Patients With the p.His123Arg in GDAP1



Subjects were censored at current age or at death.

their median year of birth being 1855 (range 1837-1882). Of interest, 31 of the 35 ancestors had been born in 2 clusters of municipalities, 1 in the north east of the province and 1 in the west coast (Figure 2).

\section{Discussion}

We found that CMT associated with p.His123Arg in GDAP1 had onset at young adulthood, but the onset varied markedly so that the proportion of affected subjects increased almost in a linear fashion between ages 5 and 73 years. The onset of the disease was frequently characterized by motor symptoms, but the patients eventually developed sensory and motor axonal polyneuropathy. Of interest, EDx testing revealed a remarkable number of asymmetrical findings. Disease progression was relatively slow, as the mean $\mathrm{mRS}$ score was 1.5 among patients younger than the median, whereas it was 2.8 among those older than the median. The frequency of the mutation was $9 / 100,000$ in the adult population of Northern Ostrobothnia, and a founder effect was observed.

Muscle weakness was predominantly distal, but we found 17 patients (74\%) with proximal muscle weakness in the lower extremities. Weakness of proximal leg muscles has been reported in $13 \%$ of patients with CMT $2,{ }^{19}$ which frequency is significantly lower than that in our patients $(p<$ 0.0002 for difference). Muscle cramps have been described to be a common symptom in patients with $\mathrm{CMT}^{20,21}$ and in patients with GDAP1 mutations. ${ }^{22}$ We found that the frequency of muscle cramps (14 patients, $61 \%$ ) was similar to that in 225 patients with polyneuropathy. ${ }^{23}$ NDSs suggested that the neuropathy was slowly progressive, but severe disability was rare, and all our patients with p.His123Arg in GDAP1 remained ambulatory. In a similar fashion, previous studies have shown that various dominant mutations in GDAP1 lead to a rather mild axonal polyneuropathy. ${ }^{3,4,24,25}$ EDx testing revealed a remarkable number of asymmetrical findings, as $70 \%$ of the patients showed asymmetry, and furthermore, muscle weakness was asymmetrical in $11 \mathrm{pa}-$ tients (48\%) including 5 patients with asymmetrical sensation. CMT2 phenotype is considered symmetrical, although $10 \%$ of patients with CMT2 have been reported with asymmetrical muscle weakness in the legs. ${ }^{19}$ Our findings and previous data ${ }^{26}$ suggest that most patients with p.His123Arg present with asymmetrical features.

The p.His123Arg mutation in GDAP1 is the most common etiology of CMT in northern Finland with a prevalence of 9/ $100000 .{ }^{11}$ It is higher than that of the PMP22 duplication in this

Figure 2 Birthplaces of Ancestors in 8 Pedigrees With the p.His123Arg in GDAP1 Placed on a Map of Finland



The province of Northern Ostrobothnia is the shaded area. 
population, which is $4.8 / 100,000 .{ }^{11}$ In case series, the frequency of any GDAP1 mutation has varied from $0.7 \%{ }^{27,28}$ to $11.1 \%{ }^{4}$ whereas we have reported previously that the frequency of p.His123Arg in GDAP1 is $31.5 \%$ in our cohort of patients with $\mathrm{CMT}^{11}$ Such a high frequency suggests a founder effect. Indeed, we found that the founders in each family were from 1 of 3 municipalities in Northern Ostrobothnia, and moreover, 1 inland municipality seemed to be the founder location (Figure 2). The most distant ancestor who harbored the mutation on genealogic basis was born in the beginning of the 19th century. The second location was on the coast, but the genealogic relationship between the families in these 2 locations could not be determined. Some diseases belonging to the Finnish disease heritage show clustering of cases within the country. ${ }^{29}$ Polyneuropathy caused by the p.His123Arg mutation in GDAP1 may be similar, but there are no studies covering the entire population. Such clustering of diseases is partly due to the founder effect and partly to the Finnish population's isolation. Recent population genetic studies have revealed several geographical clusters in the population that are related to the settlement history. ${ }^{30}$ Indeed, Northern Ostrobothnia is 1 of the clusters.

We presented detailed clinical and electrophysiologic data of 23 patients with p.His123Arg in GDAP1. It seems that asymmetry of symptoms and remarkable proximal muscle weakness of the lower extremities could be defining features in patients with p.His123Arg in GDAP1. This mutation may be the most common single mutation in patients with polyneuropathy in Finland, and indeed, we encountered a cluster of the mutation within the country.

\section{Study Funding}

Grants from the Finnish Brain Foundation, Finnish Medical Foundation, Medical Research Center, University of Oulu, and Oulu University Hospital.

\section{Disclosure}

The authors declare that they have no conflict of interest. Go to Neurology.org/NG for full disclosures.

\section{Publication History}

Received by Neurology: Genetics May 12, 2021. Accepted in final form August 11, 2021.

\section{Appendix Authors}

\begin{tabular}{lll}
\hline Name & Location & Contribution \\
\hline $\begin{array}{ll}\text { Maria } \\
\text { Lehtilahti, }\end{array}$ & $\begin{array}{l}\text { Medical Research Center } \\
\text { MD }\end{array}$ & $\begin{array}{l}\text { Oulu, University of Oulu and } \\
\text { Oulu University Hospital, } \\
\text { manuscript for content, } \\
\text { Oulu, Finland; Research Unit } \\
\text { including medical writing for } \\
\text { of Clinical Neuroscience, } \\
\text { University of Oulu, Oulu, } \\
\text { Finland; Department of } \\
\text { acquisition of data }\end{array}$ \\
& $\begin{array}{l}\text { Neurology, Oulu University } \\
\text { Hospital, Oulu, Finland }\end{array}$ & \\
&
\end{tabular}

Appendix (continued)

\begin{tabular}{|c|c|c|}
\hline Name & Location & Contribution \\
\hline $\begin{array}{l}\text { Mika } \\
\text { Kallio, MD, } \\
\text { PhD }\end{array}$ & $\begin{array}{l}\text { Department of Clinical } \\
\text { Neurophysiology, Medical } \\
\text { Research Center Oulu, Oulu } \\
\text { University Hospital, Finland; } \\
\text { Research Unit of Medical } \\
\text { Imaging, Physics and } \\
\text { Technology, Faculty of } \\
\text { Medicine, University of Oulu, } \\
\text { Finland }\end{array}$ & $\begin{array}{l}\text { Major role in the acquisition } \\
\text { of data and analysis or } \\
\text { interpretation of data, } \\
\text { including medical writing for } \\
\text { content }\end{array}$ \\
\hline $\begin{array}{l}\text { Kari } \\
\text { Majamaa, } \\
\text { MD, PhD }\end{array}$ & $\begin{array}{l}\text { Medical Research Center } \\
\text { Oulu, University of Oulu and } \\
\text { Oulu University Hospital, } \\
\text { Oulu, Finland; Research Unit } \\
\text { of Clinical Neuroscience, } \\
\text { University of Oulu, Oulu, } \\
\text { Finland; Department of } \\
\text { Neurology, Oulu University } \\
\text { Hospital, Oulu, Finland }\end{array}$ & $\begin{array}{l}\text { Drafting/revision of the } \\
\text { manuscript for content, } \\
\text { including medical writing for } \\
\text { content; major role in the } \\
\text { acquisition of data; study } \\
\text { concept or design; and } \\
\text { analysis or interpretation of } \\
\text { data }\end{array}$ \\
\hline $\begin{array}{l}\text { Mikko } \\
\text { Kärppä, } \\
\text { MD, PhD }\end{array}$ & $\begin{array}{l}\text { Medical Research Center } \\
\text { Oulu, University of Oulu and } \\
\text { Oulu University Hospital, } \\
\text { Oulu, Finland; Research Unit } \\
\text { of Clinical Neuroscience, } \\
\text { University of Oulu, Oulu, } \\
\text { Finland; Department of } \\
\text { Neurology, Oulu University } \\
\text { Hospital, Oulu, Finland }\end{array}$ & $\begin{array}{l}\text { Drafting/revision of the } \\
\text { manuscript for content, } \\
\text { including medical writing for } \\
\text { content; major role in the } \\
\text { acquisition of data; study } \\
\text { concept or design; and } \\
\text { analysis or interpretation of } \\
\text { data }\end{array}$ \\
\hline
\end{tabular}

\section{References}

1. Pipis M, Rossor AM, Laura M, Reilly MM. Next-generation sequencing in CharcotMarie-Tooth disease: opportunities and challenges. Nat Rev Neurol. 2019;15(11) 644-656.

2. Cuesta A, Pedrola L, Sevilla $\mathrm{T}$, et al. The gene encoding ganglioside-induced differentiation-associated protein 1 is mutated in axonal Charcot-Marie-Tooth type 4A disease. Nat Genet. 2002;30(1):22-25.

3. Pezzini I, Geroldi A, Capponi S, et al. GDAP1 mutations in Italian axonal CharcotMarie-Tooth patients: phenotypic features and clinical course. Neuromuscul Disord. 2016;26(1):26-32

4. Sivera R, Frasquet M, Lupo V, et al. Distribution and genotype-phenotype correlation of GDAP1 mutations in Spain. Sci Rep. 2017;7(1):6677.

5. Yoshimura A, Yuan JH, Hashiguchi A, et al. Clinical and mutational spectrum of Japanese patients with Charcot-Marie-Tooth disease caused by GDAP1 variants. Clin Genet. 2017;92(3):274-280.

6. Zimon M, Baets J, Fabrizi GM, et al. Dominant GDAP1 mutations cause predominantly mild CMT phenotypes. Neurology. 2011;77(6):540-548.

7. Niemann A, Ruegg M, La Padula V, Schenone A, Suter U. Ganglioside-induced differentiation associated protein 1 is a regulator of the mitochondrial network: new implications for Charcot-Marie-Tooth disease. J Cell Biol. 2005;170(7): 1067-1078.

8. Gonzalez-Sanchez P, Satrustegui J, Palau F, Del Arco A. Calcium deregulation and mitochondrial bioenergetics in GDAP1-related CMT disease. Int J Mol Sci. 2019; 20(2):403.

9. Jerath NU, Shy ME. Hereditary motor and sensory neuropathies: understanding molecular pathogenesis could lead to future treatment strategies. Biochim Biophys Acta. 2015;1852(4):667-678.

10. Rzepnikowska W, Kochanski A. A role for the GDAP1 gene in the molecular pathogenesis of Charcot-Marie-Tooth disease. Acta Neurobiol Exp. 2018;78(1): $1-13$.

11. Marttila M, Kytövuori L, Helisalmi S, et al. Molecular epidemiology of Charcot-MarieTooth disease in Northern Ostrobothnia, Finland: a population-based study. Neuroepidemiology. 2017;49(1-2):34-39.

12. Dyck PJ, Sherman WR, Hallcher LM, et al. Human diabetic endoneurial sorbitol, fructose, and myo-inositol related to sural nerve morphometry. Ann Neurol. 1980; $8(6): 590-596$

13. Dyck PJ. Detection, characterization, and staging of polyneuropathy: assessed in diabetics. Muscle Nerve. 1988;11(1):21-32.

14. Rankin J. Cerebral vascular accidents in patients over the age of 60. II. Prognosis. Scott Med J. 1957;2(5):200-215.

15. van Swieten JC, Koudstaal PJ, Visser MC, Schouten HJ, van Gijn J. Interobserver agreement for the assessment of handicap in stroke patients. Stroke. 1988;19(5): 604-607.

16. Kärppä $M$, Syrjälä $P$, Tolonen U, Majamaa K. Peripheral neuropathy in patients with the 3243A>G mutation in mitochondrial DNA. J Neurol. 2003;250(2):216-221. 
17. Stålberg E, van Dijk H, Falck B, et al. Standards for quantification of EMG and neurography. Clin Neurophysiol. 2019;130(9):1688-1729.

18. Bromberg MB, Jaros L. Symmetry of normal motor and sensory nerve conduction measurements. Muscle Nerve. 1998;21(4):498-503.

19. Bienfait HM, Baas F, Koelman JH, et al. Phenotype of Charcot-Marie-Tooth disease type 2. Neurology. 2007;68(20):1658-1667.

20. Lousa M, Vázquez-Huarte-Mendicoa C, Gutiérrez AJ, Saavedra P, Navarro B, Tugores A. Genetic epidemiology, demographic, and clinical characteristics of Charcot-MarieTooth disease in the Island of Gran Canaria (Spain). J Peripher Nerv Syst. 2019;24(1): 131-138.

21. Johnson NE, Sowden J, Dilek N, et al. Prospective study of muscle cramps in CharcotMarie-Tooth disease. Muscle Nerve. 2015;51(4):485-488.

22. Garcia-Sobrino T, Blanco-Arias P, Palau F, et al. Phenotypical features of a new dominant GDAP1 pathogenic variant (p.R226del) in axonal Charcot-Marie-Tooth disease. Neuromuscul Disord. 2017;27(7):667-672.

23. Maxwell SK, Kokokyi S, Breiner A, Ebadi H, Bril V, Katzberg HD. Characteristics of muscle cramps in patients with polyneuropathy. Neuromuscul Disord. 2014;24(8): 671-676.
24. Sivera R, Espinós C, Vílchez JJ, et al. Phenotypical features of the p.R120W mutation in the GDAP1 gene causing autosomal dominant Charcot-Marie-Tooth disease. J Peripher Nerv Syst. 2010;15(4):334-344.

25. Pakhrin PS, Xie Y, Hu Z, et al. Genotype-phenotype correlation and frequency of distribution in a cohort of Chinese Charcot-Marie-Tooth patients associated with GDAP1 mutations. J Neurol. 2018;265(3):637-646.

26. Auranen M, Ylikallio E, Toppila J, Somer M, Kiuru-Enari S, Tyynismaa H. Dominant GDAP1 founder mutation is a common cause of axonal Charcot-Marie-Tooth disease in Finland. Neurogenetics. 2013;14(2):123-132.

27. DiVincenzo C, Elzinga CD, Medeiros AC, et al. The allelic spectrum of CharcotMarie-Tooth disease in over 17,000 individuals with neuropathy. Mol Genet Genomic Med. 2014;2(6):522-529.

28. Gentile L, Russo M, Fabrizi GM, et al. Charcot-Marie-Tooth disease: experience from a large Italian tertiary neuromuscular center. Neurol Sci. 2020;41(5):1239-1243.

29. Norio R, Nevanlinna HR, Perheentupa J. Hereditary diseases in Finland; rare flora in rare soul. Ann Clin Res. 1973;5(3):109-141.

30. Kerminen S, Havulinna AS, Hellenthal G, et al. Fine-scale genetic structure in Finland. G3. 2017;7(10):345910 05-3468. 


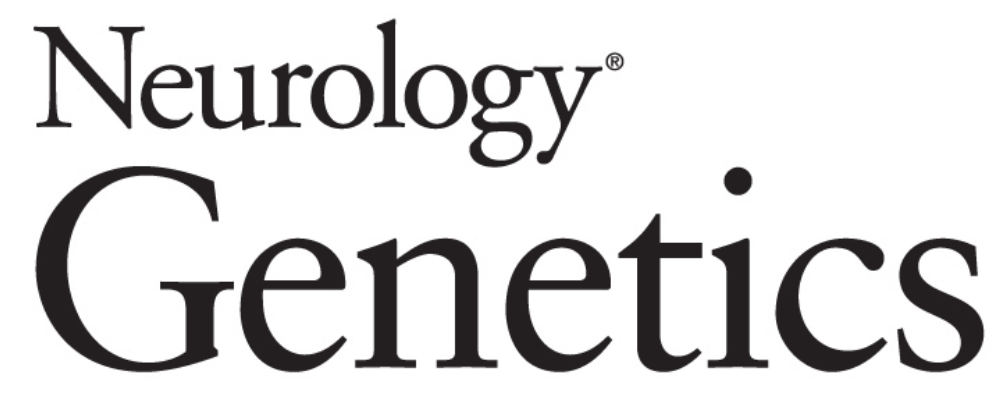

\section{Phenotype of Patients With Charcot-Marie-Tooth With the p.His123Arg Mutation in GDAP1 in Northern Finland}

Maria Lehtilahti, Mika Kallio, Kari Majamaa, et al.

Neurol Genet 2021;7;

DOI 10.1212/NXG.0000000000000629

This information is current as of October 5, 2021

\section{Updated Information \& Services}

References

Citations

Subspecialty Collections

Permissions \& Licensing

Reprints including high resolution figures, can be found at: http://ng.neurology.org/content/7/6/e629.full.html

This article cites 30 articles, 2 of which you can access for free at: http://ng.neurology.org/content/7/6/e629.full.html\#\#ref-list-1

This article has been cited by 1 HighWire-hosted articles: http://ng.neurology.org/content/7/6/e629.full.html\#\#otherarticles

This article, along with others on similar topics, appears in the following collection(s):

All Genetics

http://ng.neurology.org//cgi/collection/all_genetics

Peripheral neuropathy

http://ng.neurology.org//cgi/collection/peripheral_neuropathy

Information about reproducing this article in parts (figures,tables) or in its entirety can be found online at:

http://ng.neurology.org/misc/about.xhtml\#permissions

Information about ordering reprints can be found online: http://ng.neurology.org/misc/addir.xhtml\#reprintsus

Neurol Genet is an official journal of the American Academy of Neurology. Published since April 2015, it is an open-access, online-only, continuous publication journal. Copyright Copyright ( 2021 The Author(s). Published by Wolters Kluwer Health, Inc. on behalf of the American Academy of Neurology.. All rights reserved. Online ISSN: 2376-7839.

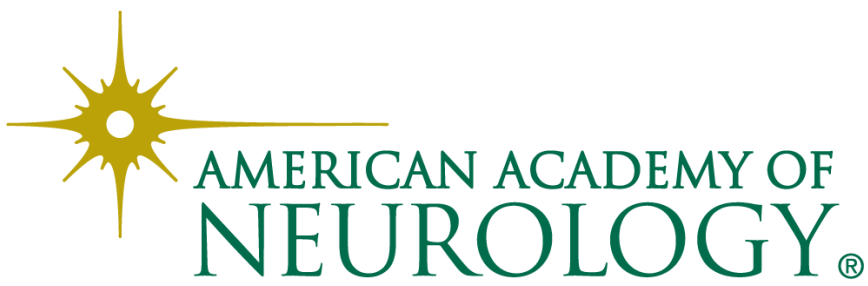

